\title{
Molasses wastewater treatment and lipid production at low temperature conditions by a microalgal mutant Scenedesmus sp. Z-4
}

Chao Ma, Hanquan Wen, Defeng Xing, Xuanyuan Pei, Jiani Zhu, Nanqi Ren and Bingfeng Liu* *

\begin{abstract}
Background: Simultaneous wastewater treatment and lipid production by oleaginous microalgae show great potential to alleviate energy shortage and environmental pollution, because they exhibit tremendous advantages over traditional activated sludge. Currently, most research on wastewater treatment by microalgal are carried out at optimized temperature conditions $\left(25-35^{\circ} \mathrm{C}\right)$, but no information about simultaneous wastewater treatment and lipid production by microalgae at low temperatures has been reported. Microalgal growth and metabolism will be inhibited at low temperature conditions, and satisfactory wastewater treatment performance will be not obtained. Therefore, it is critical to domesticate and screen superior microalgal strains with low temperature adaptability, which is of great importance for wastewater treatment and biodiesel production.
\end{abstract}

Results: In this work, simultaneous wastewater treatment and lipid production were achieved by a microalgal mutant Scenedesmus sp. Z-4 at the low temperature conditions $\left(4,10\right.$, and $\left.15^{\circ} \mathrm{C}\right)$. The results showed that algal growth was inhibited at 4,10 , and $15^{\circ} \mathrm{C}$ compared to that at the optimal temperature of $25^{\circ} \mathrm{C}$. However, decreased temperature had no significant effect on the total cellular lipid content of algae. Importantly, lipid productivity at $10^{\circ} \mathrm{C}$ was compromised by more net energy output relevant to biodiesel production, which demonstrated that the low temperature of $10^{\circ} \mathrm{C}$ was favorable to wastewater treatment and energy recovery by Scenedesmus sp. Z-4. When molasses wastewater with optimal COD concentration of $8000 \mathrm{mg} \mathrm{L}^{-1}$, initial inoculation ratio of $15 \%$, and $\mathrm{C} / \mathrm{N}$ ratio of 15 was used to cultivate microalgae, the maximum removal rate of $\mathrm{COD}, \mathrm{TN}$, and $\mathrm{TP}$ at $10^{\circ} \mathrm{C}$ reached $87.2,90.5$, and $88.6 \%$, respectively. In addition, lipid content of $28.9 \%$ and lipid productivity of $94.4 \mathrm{mg} \mathrm{L}^{-1}$ day ${ }^{-1}$ were obtained.

Conclusions: Scenedesmus sp. Z-4 had good adaptability to low temperature conditions, and showed great potential to realize simultaneous wastewater treatment and lipid production at low temperatures. The proposed approach in the study was simple compared to other wastewater treatment methods, and this potential novel process was still efficient to remove COD, $\mathrm{N}$, and $\mathrm{P}$ at low temperatures. Thus, it had a vital significance for the wastewater treatment in low temperature regions.

Keywords: Molasses wastewater, Lipid production, Low temperature, Scenedesmus sp. Z-4

\section{Background}

Energy shortage and environmental pollution have been the worldwide issues, which are mainly caused by heavy

\footnotetext{
*Correspondence: Ibf@hit.edu.cn

State Key Laboratory of Urban Water Resource and Environment, Harbin Institute of Technology, P. O. Box 2614, 73 Huanghe Road, Harbin 150090, China
}

dependence on fossil fuels [1]. Thus, alternative and sustainable biofuels (such as biodiesel, bioethanol, and biohydrogen) have attracted more and more attention due to their renewable and environmentally friendly properties. Biodiesel derived from microalgae has opened up a novel avenue to the development and utilization of clean bioenergy [2]. As one of the most promising sources for producing biodiesel, microalgae have its incomparable 
advantages compared to other biodiesel producers [3]. On one hand, it could be cultivated on non-arable lands, thus avoiding the competition with food crops [4]. On the other hand, the fast growth rate and high lipid productivity of microalgal cells are suitable for the biodiesel production. Although there are considerable advantages, the high cost of biodiesel produced by microalgae still limits their application, and it is necessary to be further reduced to meet industrial production requirement [5]. Therefore, in practice, microalgae have been cultured with wastewater instead of synthetic medium $[6,7]$, to achieve simultaneous nutrient removal and energy recovery from useless and cheap substrates.

Currently, activated sludge (AS) process is widely used in biological treatment of various kinds of wastewater. However, microalgae are also able to grow well in nutrient-rich wastewater, thus making a contribution to the reduction of pollutants and environmental sustainability [8]. Due to its potential to efficiently remove the nutrients and organics under heterotrophic/mixotrophic mode, along with the production of potentially value-added products, wastewater treatment using microalgae is gaining more attention [9]. The organic carbon and pollutants in the wastewater could be converted into cellular components such as carbohydrates and lipids, via the metabolism of microalgal cells. In addition, microalgae can assimilate inorganic nitrogen $(\mathrm{N})$ and phosphorous (P) for cell growth, which is well approved as an efficient and economical method for wastewater treatment and has been widely used in bioremediation process [10, 11].

In traditional treatment process, microorganisms existing in wastewater treatment systems (activated sludge, biofilm, etc.) belong to mesophilic bacteria, and their optimal growth temperature is $20-37^{\circ} \mathrm{C}$. However, in low temperature regions, especially in the northern regions of China, the wastewater temperature is usually below $10^{\circ} \mathrm{C}$ in the winter or spring, and the average annual temperature in Harbin City is just $4.4{ }^{\circ} \mathrm{C}$ [12]. In such conditions, the cell growth and metabolism activity of these mesophilic microorganisms are inhibited, which has a negative effect on the degradation ability of microorganisms, thus efficiency of wastewater treatment decreases in large extent. To solve this problem, increasing sludge return and hydraulic retention time (HRT), reducing sludge loading, and even artificial heating are adopted in engineering [13]. These greatly increase project investment and operation cost, but satisfactory performance of wastewater treatment is not obtained. Therefore, research on improving wastewater treatment efficiency at low temperatures will be of important theoretical and realistic significance. Microalgae with good environmental adaptability and metabolic plasticity are promising to be applied in wastewater treatment at low temperatures, compared to activated sludge process. However, the information about wastewater treatment by microalgae at low temperatures has not been reported.

Temperature is one of the most important environmental factors determining microalgal growth, which strongly affects the biomass, lipid productivity, and lipid composition of microalgae, and the effects of temperature are species dependent $[14,15]$. So far, raceway ponds and tubular photobioreactors have been widely used to culture microalgae in a large scale $[16,17]$. However, in these systems, temperature has to be maintained between 20 and $30{ }^{\circ} \mathrm{C}$ in order to obtain ideal microalgal growth and lipid accumulation because lower temperatures result in lower biomass. Most of the researches on the effect of temperature on algae are performed at controlled and optimized conditions $[18,19]$, or typical stress conditions which could be beneficial to the accumulation of some metabolites [20]. Therefore, it is important to estimate and understand the cell growth and lipid accumulation at low temperatures when subjected to low sub-optimal temperatures such as $4-15{ }^{\circ} \mathrm{C}$, and to domesticate and screen excellent microalgal strains with low temperature adaptability for wastewater treatment and biodiesel production.

In our previous research, anaerobic sludge and microalgae were co-cultured to enhance the nutrient removal and energy conversion from starch wastewater [21], and the highest COD, TN, and TP removal rate all reached above $80 \%$ when simulated starch wastewater was used as the substrate. This study will provide a novel potential for wastewater treatment by microalgae. As one of the most seriously polluted wastewater in the food industry, molasses wastewater with high concentration of COD and complex components could cause serious environmental pollution on the ecosystem [22]. Molasses wastewater by conventional anaerobic microbial treatment needs to maintain the temperature of the reactors above $30{ }^{\circ} \mathrm{C}$ [23], which increases the cost greatly because of massive energy input. In addition, complexity and high COD concentration limit the treatment and energy production. Molasses wastewater contains plenty of nutritional components such as polysaccharides, nitrate, and phosphate [24], which were essential for microalgal growth. Therefore, in this work, microalgal cells were cultivated at low temperatures for the treatment of molasses wastewater, aiming to achieve simultaneous energy recovery and nutrient removal and provide a new potential approach for wastewater treatment at low temperatures.

Scenedesmus sp. Z-4 was an oleaginous microalgal mutant, which was screened in previous experiment [25] and it has good temperature adaptability after temperature gradient domestication. The object of this study is to investigate the cell growth and lipid accumulation of 
Scenedesmus sp. Z-4 at low temperature $\left(4-15{ }^{\circ} \mathrm{C}\right)$ and determine the optimal low temperature for molasses wastewater treatment by the analysis of energy input and output related to the process of biodiesel production. The effects of culture conditions including molasses wastewater concentration, inoculation ratio, and $\mathrm{C} / \mathrm{N}$ ratio on lipid accumulation and nutrient removal were also investigated.

\section{Methods}

\section{Microalgal species and culture conditions}

The microalgal mutant Scenedesmus sp. Z-4 was used in all the following experiments. This mutant was cultured in Erlenmeyer flasks of $250 \mathrm{~mL}$ containing BG-11 medium of $150 \mathrm{~mL}$ (10\% microalgal inoculum, V/V) under white fluorescent light (3000 lux with a light/dark cycles of $12 \mathrm{~h} / 12 \mathrm{~h}$ ) in batch culture, which was supplemented with $10 \mathrm{~g} \mathrm{~L}^{-1}$ glucose and adjusted to $\mathrm{pH}$ of 7.0 and autoclaved at $121{ }^{\circ} \mathrm{C}$ for $15 \mathrm{~min}$. To ensure the metabolic activity at low temperatures, microalgal cells were cultured by decreased temperature gradient domestication of $25,20,15,10$, and $4{ }^{\circ} \mathrm{C}$, respectively. The temperatures in this experiment were set as 4, 10, and $15{ }^{\circ} \mathrm{C}$, respectively, and $25^{\circ} \mathrm{C}$ of the optimal temperature was served as the control. In the experiments of molasses wastewater treatment, the glucose in the medium was replaced by waste molasses, to provide the carbon source and nutrients for microalgal growth and lipid accumulation.

\section{Molasses wastewater}

Waste molasses was obtained from a sugar refinery factory located in Harbin, China. The initial COD concentration, total nitrogen (TN), and total phosphorus (TP) of waste molasses were approximately 514,000, 458, and $67 \mathrm{mg} \mathrm{L}^{-1}$, respectively. The main components of waste molasses are listed in Additional file 1: Table S1. To avoid the negative effect of excess COD concentration on microalgal growth, the molasses wastewater was diluted to achieve a final COD concentration of about $5000 \mathrm{mg} \mathrm{L}^{-1}$. To supply sufficient nitrogen and phosphorus sources for cell growth, TN and TP should be maintained at $600 \mathrm{mg} \mathrm{L}^{-1}$ [26] and $75 \mathrm{mg} \mathrm{L}^{-1}$ (equal to the content in BG-11 medium) by additional $\mathrm{NaNO}_{3}$ and $\mathrm{K}_{2} \mathrm{HPO}_{4}$ into the medium. In order to determine the optimal molasses concentration, original waste molasses was diluted to $5000,8000,10,000$, and $15,000 \mathrm{mg} \mathrm{L}^{-1}$, respectively. Because the ratio of $\mathrm{COD} / \mathrm{TN}$ in initial waste molasses has exceeded $1000, \mathrm{NaNO}_{3}$ had to be added into the medium to obtain final $\mathrm{C} / \mathrm{N}$ ratios of 5 , 10,15 , and 20, respectively. Fresh microalgal inoculum volumes of $7.5,15,22.5$, and $30 \mathrm{~mL}$ were transferred into molasses wastewater of $150 \mathrm{~mL}$, to make sure the inoculation ratios were $5,10,15$, and $20 \%$, respectively.

\section{The calculation of energy input and output}

The energy input consisted of (i) energy for increasing water temperature, (ii) energy for microalgal cultivation and harvesting, and (iii) energy for biodiesel production. The energy output mainly came from (iv) biodiesel combustion. The calculation was based on $1 \mathrm{~L}$ medium.

(i) The energy input for increasing water temperature $\left(\mathrm{EI}_{1}\right)$ was calculated as the following equation.

$\mathrm{EI}_{1}=c_{w} \times m \times\left(t-t_{0}\right)$,

where $c_{\mathrm{w}}$ was the specific heat capacity of water, equal to $4.2 \times 10^{3} \mathrm{~J} \mathrm{~kg}^{-1}{ }^{\circ} \mathrm{C}^{-1}$. $m$ referred to the mass of $1 \mathrm{~L}$ medium, which was assumed as $1 \mathrm{~kg}$. $t$ was the temperature applied in this study, which were $5,10,15$, and $25^{\circ} \mathrm{C}$, respectively. Considering that the temperature of winter and spring in North China was usually below $0{ }^{\circ} \mathrm{C}, t_{0}$ was set as $0{ }^{\circ} \mathrm{C}$ to simplify this calculation.

(ii) The energy input for microalgal cultivation and harvesting $\left(\mathrm{EI}_{2}\right)$ is shown in Eq. (2).

$$
\mathrm{EI}_{2}=\mathrm{EH} \times \text { biomass } \times \text { lipid content } \times 90 \%
$$

Here, an assumption was made that $90 \%$ of total fatty acids could be converted into biodiesel from the produced lipids, according to a previous study [27]. EH was the energy required for microalgal cultivation and harvesting per ton of biodiesel preparation, equal to $2288 \mathrm{kWh}^{-1}$ ton $^{-1}$ (1 $\left.\mathrm{kWh}=3.6 \times 10^{6} \mathrm{~J}\right)[28]$. Biomass and lipid content depended on the determination results at different temperature conditions.

(iii) The energy input for biodiesel production $\left(\mathrm{EI}_{3}\right)$ was obtained using the equation below.

$$
\mathrm{EI}_{3}=\mathrm{EC} \times \text { biomass } \times \text { lipid content } \times 90 \%,
$$

where EC referred to the energy consumption per ton of biodiesel production, which was equal to 9 $\mathrm{kWh}$ ton $^{-1}$ according to a previous report [29]. The transesterification efficiency was also $90 \%$ as stated above.

(iv) The energy output (EO) in the process of biodiesel combustion was calculated as the Eq. (4).

$$
\mathrm{EO}=Q \times \text { biomass } \times \text { lipid content } \times 90 \%
$$

Here, $Q$ was the energy release per $\mathrm{kg}$ of biodiesel combustion, equal to $39.51 \mathrm{MJ} / \mathrm{kg}$ [30].

\section{Analytical methods}

Biomass was collected by centrifugation, followed by washing of normal saline, and then weighted on an electronic scale after drying at $105{ }^{\circ} \mathrm{C}$ until constant weight was obtained. Lipid was extracted and determined as per 
the procedures in the literature [31]. Briefly, the lipids were extracted from dried biomass with a solvent mixture of chloroform/methanol $(2: 1, \mathrm{v} / \mathrm{v})$. The supernatant was recovered and the same process was carried out two times for the complete extraction of lipids. After the determination of biomass and lipid content, lipid productivity could be calculated according to the following equation.

Lipid productivity $\left(\mathrm{mg} \mathrm{L}^{-1}\right.$ day $\left.^{-1}\right)=$ biomass $\times$ lipid content $/ t$

Here, $t$ was the cultivation time (d), and equal to 7 days in our experiments. This was due to the maximum lipid productivity obtained on the 7 th day (Additional file 1 : Figure S1).

The fatty acid composition analysis was performed using the methods previously described [32]. The solvent phase was combined, dried, and weighed. The chemical oxygen demand (COD), total nitrogen (TN), and total phosphorus (TP) were measured according to the methods described previously [33-35]. The glucose concentration in the culture broth was determined by the method in our previous study [26]. Polysaccharide content was measured by the phenol and sulfuric acid method described in a previous literature [36]. Protein content was obtained using UV-vis based on the Bradford method [37]. All experiments were conducted in triplicate, and data were recorded as the mean with standard deviation (SD). Fluorescence microscope (BX51/ TF, Olympus Co., Japan) was applied to observe cells stained with Nile Red (0.1 mg mL ${ }^{-1}$ acetone solution), and the excitation and emission wavelength were 530 and $575 \mathrm{~nm}$, respectively. The pictures of microalgal cells and oil bodies were acquired randomly from at least 10 cells per sample, and typical images are shown here.

\section{Results and discussion}

The cell growth and lipid production of Scenedesmus sp.

\section{Z-4 at low temperature conditions}

The microalgae strain Scenedesmus sp. Z-4 with Nile red staining at different temperatures of $4,10,15$, and $25^{\circ} \mathrm{C}$ are shown in Fig. 1a-d. Microscopic observation showed that fluorescence intensity and the amount of lipid droplets in microalgal cells increased with the increase of culture temperature from $4-25{ }^{\circ} \mathrm{C}$. Low fluorescence intensity was observed at $4{ }^{\circ} \mathrm{C}$, indicating that low content of lipid existed in the cells of strain Z-4 (Fig. 1a). This result was not surprising because $4{ }^{\circ} \mathrm{C}$ was usually used as the temperature for culture preservation and microorganisms almost ceased to grow at this temperature.

To further investigate quantitatively the cell growth and lipid production at low temperatures, the biomass, and

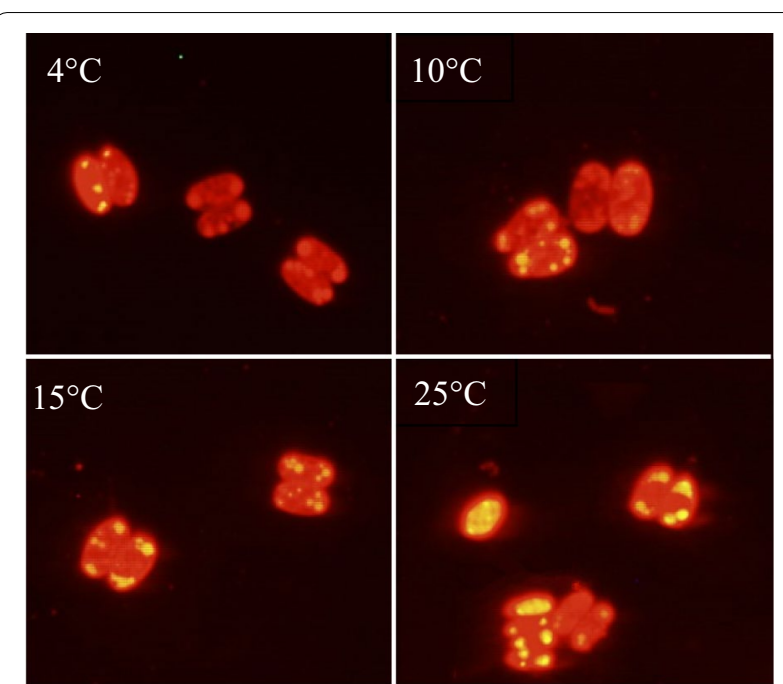

Fig. 1 Fluorescence micrograph of microalgal strain Z-4 staining with Nile red at different temperatures

lipid productivity were determined at $4,10,15$, and $25^{\circ} \mathrm{C}$, respectively. As shown in Fig. 2, with the temperature increasing from 4 to $25{ }^{\circ} \mathrm{C}$, lipid content, biomass, and lipid productivity all gradually increased. The obtained maximum lipid productivity of $125 \mathrm{mg} \mathrm{L}^{-1} \mathrm{day}^{-1}$ at the optimal temperature of $25{ }^{\circ} \mathrm{C}$ was evidently higher than that at low temperatures of 4,10 , and $15{ }^{\circ} \mathrm{C}(63,78$, and $86 \mathrm{mg} \mathrm{L}^{-1}$ day $^{-1}$, respectively). This was due to the inhibition of cellular metabolism at low temperatures, especially low enzymatic activities responsible for cell growth and lipid accumulation [38].

Furthermore, the low temperature had a more significant effect on biomass compared to the lipid content. There was a great difference in the final biomass at the optimal temperature $\left(3.4 \mathrm{~g} \mathrm{~L}^{-1}\right.$ at $\left.25{ }^{\circ} \mathrm{C}\right)$, compared to

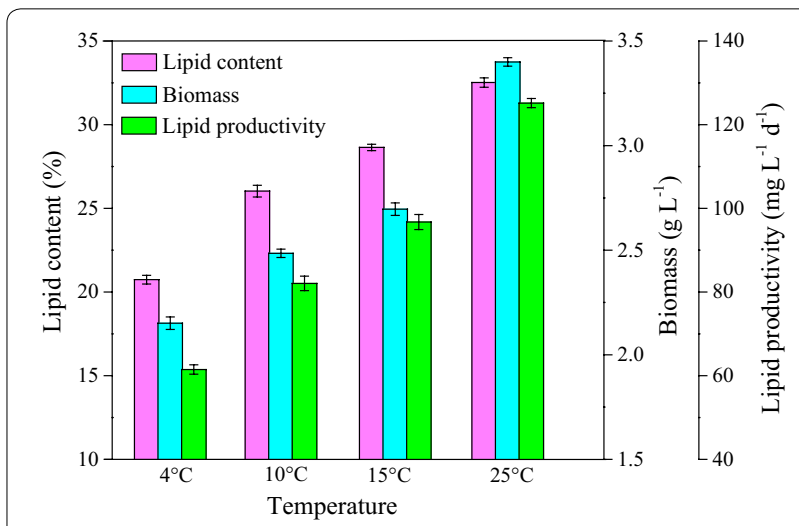

Fig. 2 Biomass and lipid accumulation of strain Z-4 at different temperatures 
that at low temperatures of 4,10 , and $15{ }^{\circ} \mathrm{C}(1.8,2.6$, and $2.8 \mathrm{~g} \mathrm{~L}^{-1}$, respectively). However, the lipid contents at the low temperatures were 20,26 , and $28 \%$ for 4,10 , and $15{ }^{\circ} \mathrm{C}$, respectively, which was still comparable to that at stress temperature in some literatures $[39,40]$. This result showed that the lipid content may be an inherent characteristic for the oleaginous mutant Scenedesmus sp. Z-4, which was not easily affected by the environmental factors such as the temperature. Even though the biomass and lipid productivity at the temperatures of 10 and $15{ }^{\circ} \mathrm{C}$ were lower than that at $25^{\circ} \mathrm{C}$, they were considerable enough for the potential of wastewater treatment.

Because not all the fatty acids were suitable for transesterification to biodiesel, the compositions of fatty acids at 4,10 , and $15^{\circ} \mathrm{C}$ were examined to determine whether the fatty acids produced at low temperatures were suitable for the biodiesel production. The main fatty acids at different temperatures were from $\mathrm{C} 14$ to $\mathrm{C} 20$, which indicated the dominance of long-chain fatty acids (Table 1).

The compositions of main fatty acids at different temperatures were almost the same, especially the four fatty acids, including palmitic acid (C 16:0), stearic acid (C 18:0), oleic acid (C 18:1 w9c), and linoleic acid (C 18:2 w6,9c), accounted for more than $90 \%$ of total fatty acids. The tiny distinctions lay in more palmitic acid (C 16:0) and oleic acid (C 18:1 w9c) and less linoleic acid (C 18:2 w6,9c) at the temperatures 10,15 , and $25^{\circ} \mathrm{C}$, compared to that at $4{ }^{\circ} \mathrm{C}$. It should be noted that more linolenic acid (C $18: 3$ w6c) was obtained at the temperature of $4{ }^{\circ} \mathrm{C}$. It has been reported that more saturated fatty acids (C 16:0 and C 18:0) and less unsaturated fatty acids (C 18:2 and C 18:3) were suitable for the biodiesel production [41]. This result implied that the compositions of fatty acids at the temperature of $4{ }^{\circ} \mathrm{C}$ may not be applicable in transesterification.

To further investigate the variation of cellular components at different temperatures, the contents of polysaccharide, lipid, and protein at the temperatures of 4, 10, 15 , and $25^{\circ} \mathrm{C}$ were determined (Fig. 3). Result showed highest percentage of polysaccharide accounted for $46 \%$ at the temperature of $4{ }^{\circ} \mathrm{C}$, which was in agreement with a previous study that starch accumulation was observed under growth-inhibiting conditions, to protect cellular structures and increase the microalgae survival probability [42]. Furthermore, with the temperature increasing from 4 to $25^{\circ} \mathrm{C}$, the content of lipid and protein gradually increased, and the content of polysaccharide decreased. It was not in consistent with a previous study by Ho et al. [43], which showed that carbohydrate and lipid both accumulated in case of nitrogen starvation. This could be attributed to severe nitrogen deficiency caused by the prolonging of cultivation time, therefore, carbohydrate and lipid were largely produced. However, with the temperature increasing from 4 to $25^{\circ} \mathrm{C}$ in this study, the
Table 1 The compositions of fatty acids (mass percentage) of microalgal strain Z-4 at different temperatures

\begin{tabular}{|c|c|c|c|c|}
\hline $\begin{array}{l}\text { Compositions } \\
\text { of fatty acids }\end{array}$ & $4^{\circ} \mathrm{C}$ & $10^{\circ} \mathrm{C}$ & $15^{\circ} \mathrm{C}$ & $25^{\circ} \mathrm{C}$ \\
\hline C $15: 02 \mathrm{OH}$ & $0.67 \pm 0.12$ & - & $0.47 \pm 0.13$ & $0.33 \pm 0.11$ \\
\hline $\mathrm{C} 15: 03 \mathrm{OH}$ & $0.20 \pm 0.07$ & - & $0.22 \pm 0.07$ & - \\
\hline C 16:0 & $35.98 \pm 2.03$ & $38.51 \pm 3.28$ & $38.98 \pm 3.56$ & $39.51 \pm 3.71$ \\
\hline C 17:1 w8c & - & $0.22 \pm 0.10$ & - & $0.19 \pm 0.07$ \\
\hline C 18:1 W7c & $0.43 \pm 0.09$ & $0.25 \pm 0.09$ & $0.43 \pm 0.11$ & - \\
\hline C 18:1 w9c & $25.92 \pm 1.64$ & $27.92 \pm 2.34$ & $28.43 \pm 2.62$ & $29.18 \pm 2.53$ \\
\hline $18: 2 w 6,9 c$ & $18.22 \pm 1.35$ & $13.50 \pm 1.13$ & $14.24 \pm 1.64$ & $15.50 \pm 1.42$ \\
\hline $\begin{array}{r}18: 3 w 6 c \\
(6,9,12)\end{array}$ & $3.86 \pm 0.59$ & $1.90 \pm 0.31$ & $1.86 \pm 0.28$ & $1.58 \pm 0.34$ \\
\hline C 20:0 & $0.30 \pm 0.11$ & $0.28 \pm 0.07$ & $0.29 \pm 0.10$ & $0.26 \pm 0.08$ \\
\hline C 20:1 w9c & $0.17 \pm 0.04$ & $0.18 \pm 0.06$ & $0.17 \pm 0.08$ & $0.20 \pm 0.09$ \\
\hline $\begin{array}{l}\text { Saturated fatty } \\
\text { acids }\end{array}$ & $47.41 \pm 2.33$ & $52.55 \pm 3.35$ & $53.41 \pm 3.86$ & $55.56 \pm 3.90$ \\
\hline $\begin{array}{l}\text { Unsaturated } \\
\text { fatty acids }\end{array}$ & $53.59 \pm 3.71$ & $47.44 \pm 4.03$ & $46.59 \pm 4.73$ & $44.44 \pm 4.45$ \\
\hline
\end{tabular}

negative influence of stress environment on microalgal cells started to weaken. Cell growth and metabolic activities enhanced with the increase of temperature and more energy substances (such as polysaccharide) could be utilized to the accumulation of lipid.

As well known, the microorganisms at low temperatures could not utilize the substrate well, which was due to lower cellular activity. The glucose consumption at different temperatures in the course of microalgal growth is clearly presented in Fig. 4 . In the cultivation process of 8 days, utilization rate of glucose was only approximately $40 \%$, which suggested that inefficient substrate uptake was unfavorable to cell growth and lipid accumulation. In contrast, glucose concentration was almost zero on the 7 th day at the temperature of $25^{\circ} \mathrm{C}$. Approximately $80 \%$ of glucose was consumed at the low temperatures of 10 and $15{ }^{\circ} \mathrm{C}$, which was still an acceptable result.

Here, a summary was made to compare the biomass, lipid productivity, compositions of fatty acids, cellular components, and glucose consumption at the temperatures of $4,10,15$, and $25^{\circ} \mathrm{C}$. As shown in Additional file 1: Table S2, a conclusion could be drawn that $4{ }^{\circ} \mathrm{C}$ was not suitable for wastewater treatment because the cell growth, lipid accumulation, and substrate utilization at this temperature were not satisfactory.

\section{The energy conversion efficiency and feasibility of wastewater treatment by Scenedesmus sp. Z-4 at low temperature conditions \\ Energy conversion efficiency at different temperature}

As stated above, the desirable lipid productivity, fatty acids composition, and intracellular components were 


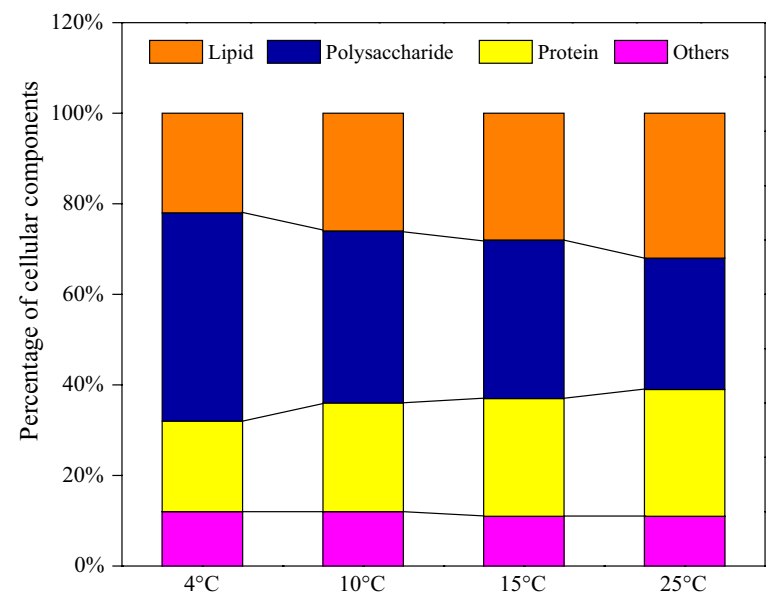

Fig. 3 Percentage of main cellular components of microalgal strain Z-4 at different temperatures

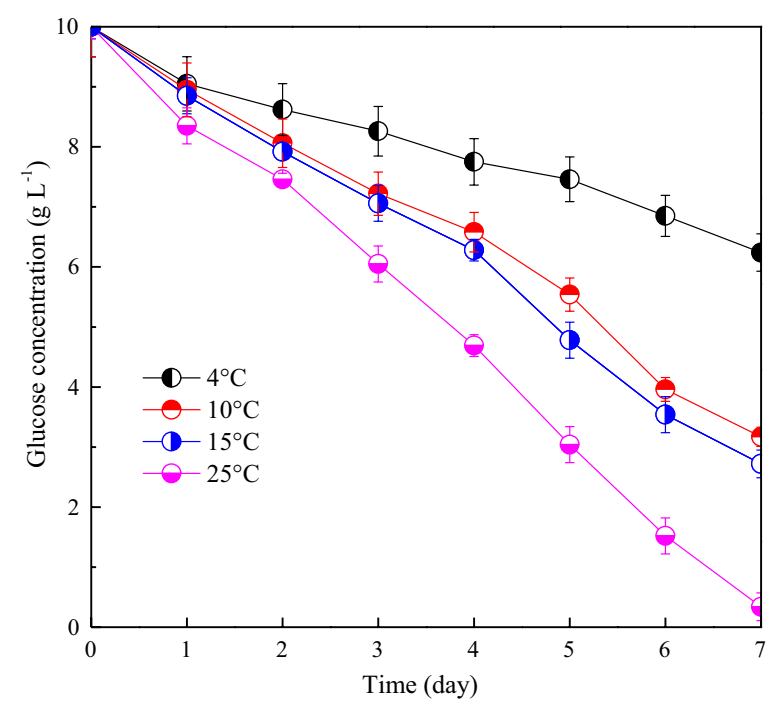

Fig. 4 Time course profiles of glucose concentration for strain Z-4 at different temperatures obtained at the low temperatures of 10 and $15{ }^{\circ} \mathrm{C}$, even though they were not as high as that at the optimal temperature. However, maintaining the suitable temperature of $25-30{ }^{\circ} \mathrm{C}$ for the microalgal growth meant more energy input. If net energy output did not significantly increase at the optimal temperature, it would not be recommended in terms of economics. It should be noted that the wastewater temperature was lower than $10^{\circ} \mathrm{C}$ in the winter and spring of northeastern regions in China, and the growth and metabolism of most mesophilic functional microorganisms were largely inhibited at the low temperatures. Although the artificial heating could improve the efficiency of wastewater treatment, the energy consumption and operation cost would greatly increase.

A heat value comparison of energy input and output in $1 \mathrm{~L}$ pure BG-11 medium was calculated at different temperatures. As shown in Table 2, the energy input was mainly from three parts, increasing water temperature, microalgal cultivation and harvesting, and biodiesel production. The first part dominated the total energy input. The results showed that with the temperature increasing from 4 to $25^{\circ} \mathrm{C}$, more energy input was required to increase the temperature of cultivation system, however, the differences in energy demand for microalgal cultivation and harvesting and biodiesel production at different temperatures were almost negligible, leading to a great difference in total energy input at various temperatures (19.92, 47.22, 69.26, and $112.38 \mathrm{~kJ}$, respectively). On the other hand, considerable energy output derived from biodiesel was not obtained with the increasing of temperature, and $33.74 \mathrm{~kJ}$ of energy output at $25^{\circ} \mathrm{C}$ was not obviously higher than that $(22.43 \mathrm{~kJ})$ at $10{ }^{\circ} \mathrm{C}$. The overall effect was that net energy output and the ratio of output/ input significantly decreased, from 4 to $25^{\circ} \mathrm{C}$. This demonstrated that more energy input was needed in higher temperature, which was not cost effective from the perspective of economics.

Table 2 The calculation of energy input and output (kJ) for microalgae biodiesel process at different temperatures

\begin{tabular}{|c|c|c|c|c|c|c|c|}
\hline \multirow{2}{*}{$\begin{array}{l}\text { Temperature } \\
\left({ }^{\circ} \mathrm{C}\right)\end{array}$} & \multicolumn{4}{|l|}{ Energy input ${ }^{a}$} & \multirow{2}{*}{$\begin{array}{l}\text { Energy Output } \\
\text { Biodiesel }\end{array}$} & \multirow{2}{*}{$\begin{array}{l}\text { Net energy } \\
\text { output }\end{array}$} & \multirow[t]{2}{*}{ Output/input } \\
\hline & $\begin{array}{l}\text { Water heating } \\
\mathrm{El}_{1}\end{array}$ & $\begin{array}{l}\text { Cultivation } \\
\text { and harvesting } \\
\mathrm{El}_{2}\end{array}$ & $\begin{array}{l}\text { Biodiesel prepa- } \\
\text { ration } \mathrm{El}_{3}\end{array}$ & $\begin{array}{l}\text { Sum of energy } \\
\text { input }\end{array}$ & & & \\
\hline 4 & 16.8 & 3.11 & 0.012 & 19.92 & 13.42 & -6.50 & 0.67 \\
\hline 10 & 42 & 5.20 & 0.020 & 47.22 & 22.43 & -24.79 & 0.48 \\
\hline 15 & 63 & 6.23 & 0.025 & 69.26 & 26.87 & -42.39 & 0.39 \\
\hline 25 & 105 & 7.35 & 0.031 & 112.38 & 33.74 & -78.64 & 0.30 \\
\hline
\end{tabular}

\footnotetext{
a The data were calculated based on $1 \mathrm{~L}$ pure medium
} 
Moreover, when wastewater was used to cultivate microalgae, lipid productivity would decrease to some extent, which had a negative effect on biodiesel yield. However, a large amount of energy was still needed to maintain the cultivation temperature condition, leading to a further decrease of the ratio between energy output to input, which was not favorable to wastewater treatment and energy recovery. If satisfactory wastewater treatment performance was obtained at the low temperature, the treatment method should be proposed. Highest ratio of output/input was obtained at $4{ }^{\circ} \mathrm{C}$, but the biomass and lipid accumulation were too low, which have been discussed above. Beside $4{ }^{\circ} \mathrm{C}$, best ratio of output/ input occurred at $10^{\circ} \mathrm{C}$. By comprehensive consideration of lipid productivity, the cost of wastewater treatment and the ratio of energy output/input, $10{ }^{\circ} \mathrm{C}$ was the best low temperature condition.

\section{Wastewater treatment by Scenedesmus sp. Z-4 at low temperature conditions}

Furthermore, this work tested the COD, TN, and TP removal by Scenedesmus sp. Z-4 at the temperatures of 4, 10, 15, and $25{ }^{\circ} \mathrm{C}$ (Fig. 5). After several domestication of molasses wastewater, the highest removal rate of COD, $\mathrm{TN}$, and TP was obtained at the optimal temperatures of $25{ }^{\circ} \mathrm{C}, 86.6,84.5$, and $83.3 \%$, respectively. For the performance at $4{ }^{\circ} \mathrm{C}$, it showed poor removal rates with COD, $\mathrm{TN}$, and TP at the temperature, which may be due to the inactive cellular metabolism at this temperature. Higher removal rates of $\mathrm{COD}, \mathrm{TN}$, and $\mathrm{TP}$ were still obtained at the low temperatures of 10 and $15{ }^{\circ} \mathrm{C}$, even though slightly lower than that at $25{ }^{\circ} \mathrm{C}$. These results showed satisfactory wastewater treatment efficiency at the low temperature of $10{ }^{\circ} \mathrm{C}$, which showed the feasibility of simultaneous energy recovery and nutrient removal from molasses wastewater.

In the following work, to enhance the wastewater treatment performance and simultaneous lipid production by strain Z-4, the optimization of initial molasses concentration, inoculation ratio, and ratio of $\mathrm{C} / \mathrm{N}$ in the medium were carried out, and their effects on lipid production and removal rate of COD, TN, and TP were also investigated.

\section{Treatment performance of molasses wastewater at the low temperature of $10^{\circ} \mathrm{C}$ \\ The effect of initial molasses concentration on lipid production and wastewater treatment}

The concentration of organic matters in wastewater treatment system had a significant effect on the microbial growth and metabolism [43]. Excessively high or low concentration was unfavorable to microbial growth and accumulation of metabolites.

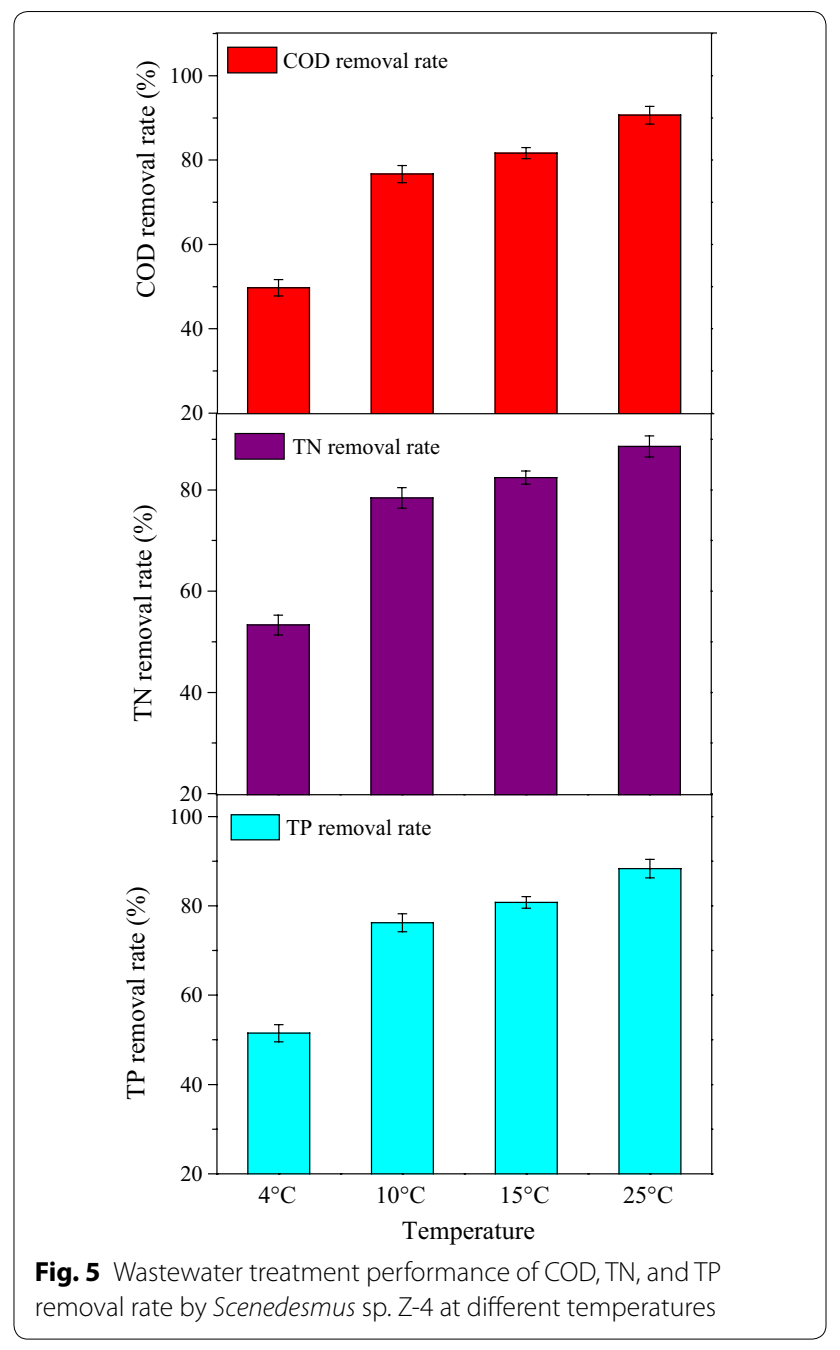

To investigate the effect of initial molasses concentration on wastewater treatment and lipid accumulation of strain Z-4 at $10{ }^{\circ} \mathrm{C}$, the initial COD of molasses was set as $5000,8000,10,000$, and $15,000 \mathrm{mg} \mathrm{L}^{-1}$, respectively. As shown in Fig. 6a, when the molasses concentration increased from 5000 to $8000 \mathrm{mg} \mathrm{L}^{-1}$, biomass/lipid productivity significantly increased from $2.3 \mathrm{~g} \mathrm{~L}^{-1} / 68.2 \mathrm{mg}$ $\mathrm{L}^{-1}$ day $^{-1}$ to $2.8 \mathrm{~g} \mathrm{~L}^{-1} / 86.4 \mathrm{mg} \mathrm{L}^{-1}$ day $^{-1}$. This suggested that the increase in molasses concentration was beneficial to cell growth and lipid accumulation, which could be attributed to the vigorous metabolism of strain Z-4 at low molasses concentration. However, while the molasses concentration further increased to 10,000 and $15,000 \mathrm{mg} \mathrm{L}^{-1}$, biomass and lipid productivity decreased to $2.5 \mathrm{~g} \mathrm{~L}^{-1} / 80.5 \mathrm{mg} \mathrm{L}^{-1}$ day $^{-1}$ and $2.1 \mathrm{~g} \mathrm{~L}^{-1} / 72.8 \mathrm{mg} \mathrm{L}^{-1} \mathrm{day}^{-1}$, respectively. Results indicated that excessive high molasses concentration in the medium had a negative effect on the energy production for strain Z-4. 

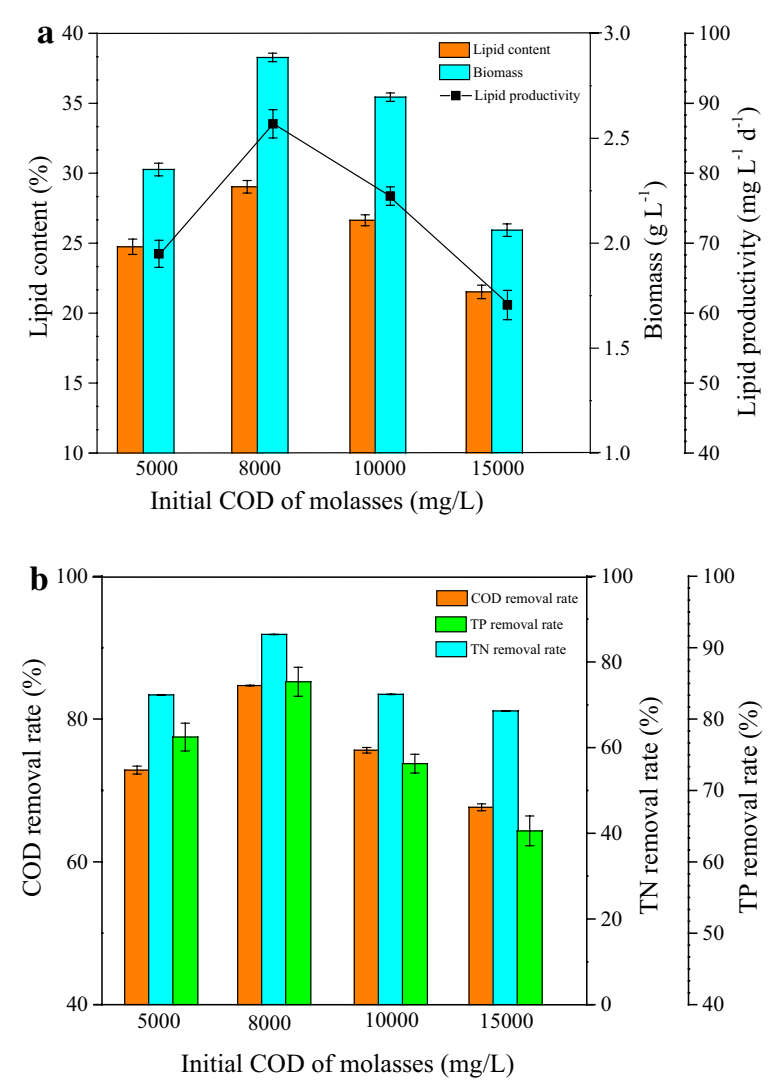

Fig. 6 Effect of initial molasses concentration on lipid accumulation and wastewater treatment performance at $10^{\circ} \mathrm{C}$ by strain Z-4 a Cellular growth and lipid production. b COD, TN, and TP removal rate

Furthermore, removal rate of COD, TN, and TP at $10{ }^{\circ} \mathrm{C}$, supplemented with initial molasses concentration of 5000, 8000, 10,000 and 15,000 $\mathrm{mg} \mathrm{L}^{-1}$ was studied (Fig. 6b). When the concentration increased from 5000 to $8000 \mathrm{mg} \mathrm{L}^{-1}$, removal rate of COD, TN, and TP evidently increased from $73.2,72.4,77.5$ to $85.6,84.4$, $83.7 \%$, respectively. The further increase of molasses concentration would result in the gradual decrease to $68.6,69.5$, and $64.5 \%$ at $15,000 \mathrm{mg} \mathrm{L}^{-1}$, which showed a similar tendency to cellular growth. It should be noted that more lipid or COD removal rate could be obtained compared with other reported studies [44, 45] when molasses wastewater was used as the substrate, which verified the potential of strain Z-4 for simultaneous lipid production and wastewater treatment.

In this study, an appropriate molasses concentration could favor the wastewater treatment and energy production by strain Z-4, and thus molasses with $8000 \mathrm{mg} \mathrm{L}^{-1}$ of COD would be adopted in the following experiments.

\section{The effect of inoculation ratio on lipid production and wastewater treatment}

The inoculation ratio $(\mathrm{V} / \mathrm{V})$ had a remarkable influence on the lag phase of microorganisms [46]. When the inoculation ratio was high, microbial community could enter into logarithmic phase quickly. However, excessive initial inoculation ratio would be the limiting factor for microbial growth, which had an important effect on the metabolism of microorganism, including lipid accumulation. Therefore, it was crucial to investigate the correlation between microalgal inoculation ratio and wastewater treatment performance.

To determine the optimal inoculation ratio, initial inoculation ratio of $5,10,15$, and $20 \%$ were chosen for the experiments. Biomass and lipid productivity obviously increased from $2.2 \mathrm{~g} \mathrm{~L}^{-1} / 61.4 \mathrm{mg} \mathrm{L}^{-1}$ day $^{-1}$ to $2.9 \mathrm{~g}$ $\mathrm{L}^{-1} / 92.3 \mathrm{mg} \mathrm{L}^{-1}$ day $^{-1}$ when inoculation ratio increased from 5 to $15 \%$ (Fig. 7 ). This could be attributed to the sufficient nutrients in the culture system, which was beneficial to the microalgal growth and lipid production, when the inoculation ratio was less than $15 \%$. However, while inoculation ratio further increased to $20 \%$, biomass and lipid productivity visibly decreased to $2.3 \mathrm{~g} \mathrm{~L}^{-1}$ and $65.5 \mathrm{mg} \mathrm{L}^{-1}$ day $^{-1}$, respectively. The reason could be deficient nutritional components which inhibited microalgal growth and lipid accumulation.

Wastewater treatment performance of COD, TN, and TP removal rate was in accordance with cell growth and lipid accumulation (Fig. 8). The optimal removal rate of COD, TN, TP was $86.4,87.9$, and $85.2 \%$, respectively, which was obtained under the initial inoculation ratio of $15 \%$. In previous studies, microalgae were mixed with

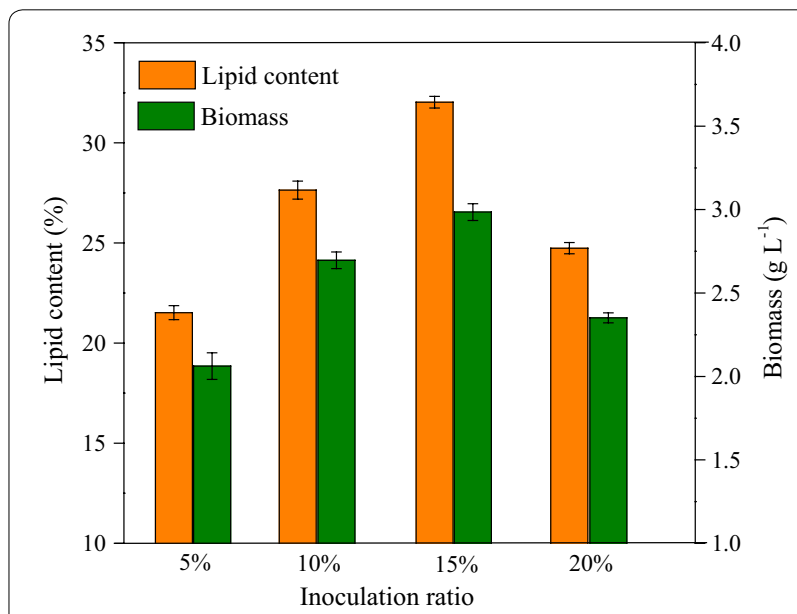

Fig. 7 Effect of inoculant volume on microalgal cell growth and lipid production of strain Z-4 at $10^{\circ} \mathrm{C}$ 


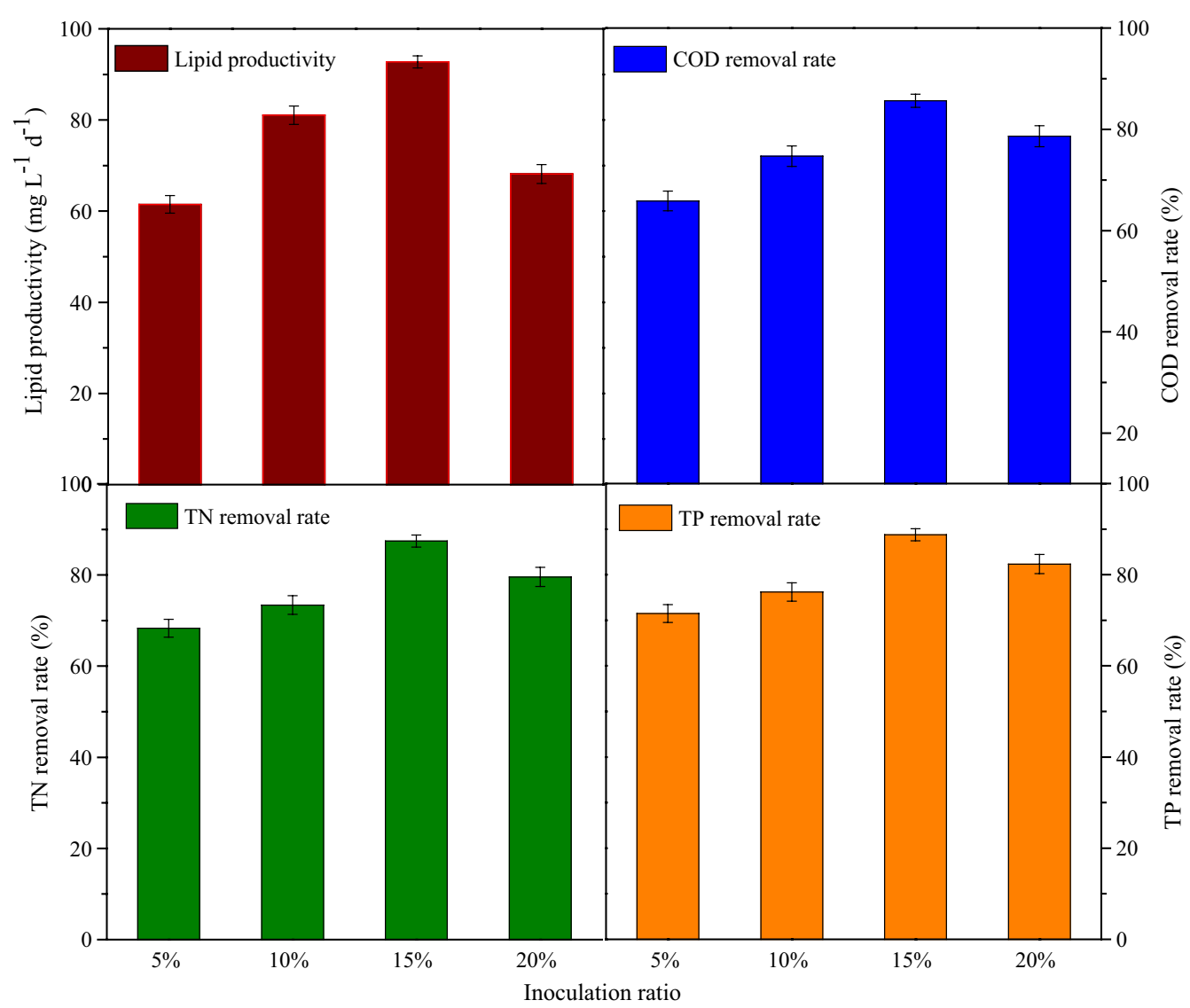

Fig. 8 Effect of inoculant volume on wastewater treatment performance of COD, TN, and TP removal rate by strain Z-4 at $10^{\circ} \mathrm{C}$

anaerobic sludge [21] or activated sludge [47] to treat various wastewaters and the optimal mixed ratio was investigated. However, in this study, it was demonstrated that strain Z-4 only could reach better wastewater treatment performance under the optimized inoculation ratio.

It should be noted that the optimal microalgal inoculation ratio was $15 \%$ for molasses wastewater system, which was higher than that for BG-11 medium (10\%). This may be due to the relatively complex components of molasses, compared to the pure medium, and thus demanded more microalgal cells to activate the cultivation system.

\section{The effect of ratio of $\mathrm{C} / \mathrm{N}$ on lipid production and wastewater treatment}

The ratio of $\mathrm{C} / \mathrm{N}$ was of great importance to cellular metabolism, which regulated the balance between microalgal growth and lipid accumulation. As shown in Fig. 9, when the ratio of $\mathrm{C} / \mathrm{N}$ was 5 , the highest biomass of 3.4 $\mathrm{g} \mathrm{L}^{-1}$ was obtained, while the lipid content and productivity were relatively low. The highest lipid content was determined at the ratio of $\mathrm{C} / \mathrm{N}$ of 20 , but the biomass was lowest. This result was similar with previous studies
[48], which demonstrated that low $\mathrm{C} / \mathrm{N}$ was beneficial to cell growth and biomass accumulation, while high ratio of $\mathrm{C} / \mathrm{N}$ was in favor of lipid synthesis. Therefore, in a two-stage cultivation of microalgae, low $\mathrm{C} / \mathrm{N}$ should be applied in the first stage to harvest more biomass, and

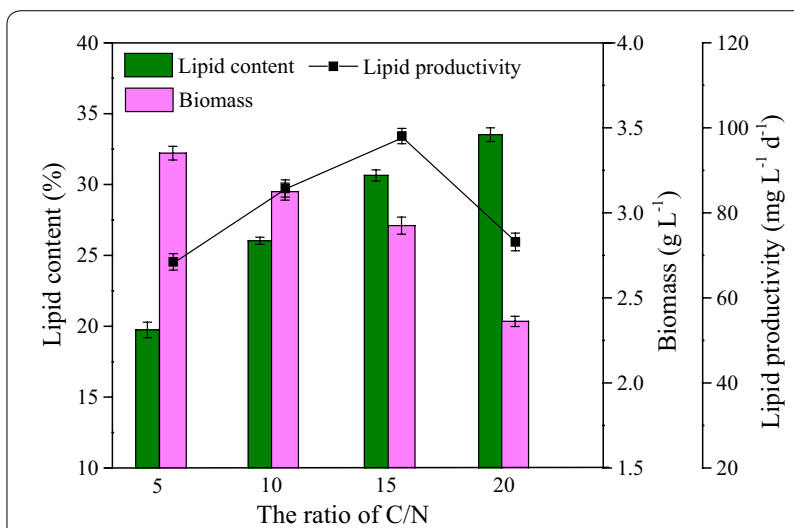

Fig. 9 Effect of $C / N$ ratio on cellular growth and lipid production of strain Z-4 at $10^{\circ} \mathrm{C}$ 
high $\mathrm{C} / \mathrm{N}$ was followed in the second stage to enhance the lipid accumulation, which could be an effective approach to obtain more biomass and lipid in two-stage system by adjusting $\mathrm{C} / \mathrm{N}$. However, when the ratio of $\mathrm{C} / \mathrm{N}$ was at 15 , highest lipid productivity of $94.4 \mathrm{mg} \mathrm{L}^{-1}$ day $^{-1}$ was obtained even though biomass of $3.0 \mathrm{~g} \mathrm{~L}^{-1}$ and lipid content of $28.9 \%$ were not the optimal, which should be attributed to the balance between cell growth and lipid accumulation caused by the appropriate ratio of $\mathrm{C} / \mathrm{N}$.

The wastewater treatment performance was also investigated under different ratios of $\mathrm{C} / \mathrm{N}$. As was indicated in Fig. 10 , when $\mathrm{C} / \mathrm{N}$ was at low ratios of 5 and 10 , higher COD removal rate was observed, which was demonstrated by more biomass accumulation; however, low TN removal rates of 67.5 and $74.3 \%$ were caused by excessive nitrogen concentration. When $\mathrm{C} / \mathrm{N}$ was high at the ratio of 20, insufficient nitrogen was the main limiting factor, which inhibited cell growth and wastewater treatment

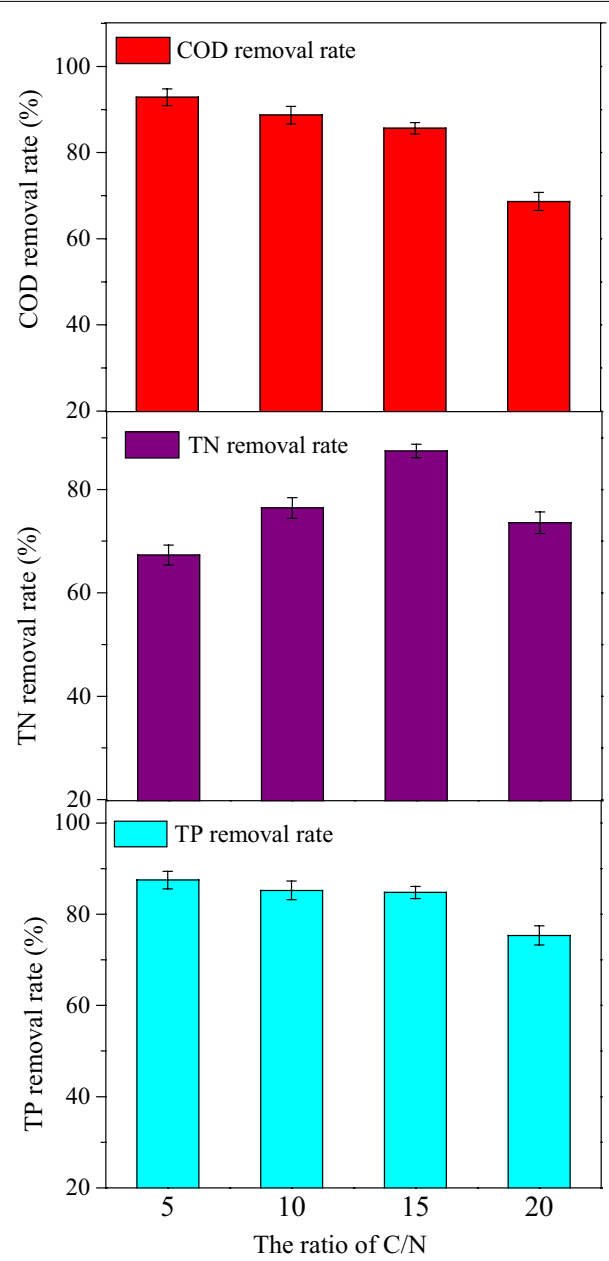

Fig. 10 Effect of $\mathrm{C} / \mathrm{N}$ ratio on wastewater treatment performance by strain Z-4 at $10^{\circ} \mathrm{C}$ performance. Thus, it could be concluded that the optimal ratio of $\mathrm{C} / \mathrm{N}$ was 15 , by combining the results of microalgal metabolism with the removal rate of COD (87.2\%), nitrogen (90.5\%), and phosphorus (88.6\%).

Here, a short conclusion could be reached that the maximum removal rate of $\mathrm{COD}, \mathrm{TN}$, and $\mathrm{TP}$ at $10{ }^{\circ} \mathrm{C}$ were $87.2,90.5$, and $88.6 \%$, respectively, when molasses wastewater with optimal COD concentration of $8000 \mathrm{mg}$ $\mathrm{L}^{-1}$, initial inoculation ratio of $15 \%$, and $\mathrm{C} / \mathrm{N}$ ratio of 15 were applied in the experiments. Furthermore, the lipid content of $28.9 \%$ and lipid productivity of $94.4 \mathrm{mg}$ $\mathrm{L}^{-1}$ day $^{-1}$ were also obtained.

\section{Comparisons between the proposed approach in this study with other wastewater treatment processes Comparison with current molasses wastewater treatment techniques}

As shown in Table 3, various molasses wastewater treatment techniques were compared. Traditionally, molasses wastewater was treated by activated sludge (AS), and microalgae and ozonation have been coupled to enhance treatment performance $[45,49]$. On one hand, aeration was essential to maintain the metabolic activity of aerobic bacteria in AS process, which needed large amount of energy input. On the other hand, the combined wastewater systems were not easy to control, and COD removal rates were 78 and $66.5 \%$, which were not satisfactory results. Even though higher removal rate of COD (98.2\%), TN (90.2\%), and TP (85.5\%) were obtained in another combined system, which could be mainly attributed to the treatment of AFBR (anaerobic fixed bed reactor), and microalgae pond was only a post-treatment unit. Undoubtedly, extra treatment units would increase the cost of wastewater treatment. Microbial fuel cells (MFC) were also applied to simultaneous molasses wastewater treatment and electricity generation [50]. However, biodiesel derived from microalgae was a better alternative, compared to electricity recovery. Importantly, these treatment methods were conducted at about $30{ }^{\circ} \mathrm{C}$, to ensure microbial metabolism and activity. Once the temperature decreased to a low level, the performance of wastewater treatment would significantly decrease. However, in this study strain Z-4 was cultivated with molasses wastewater at the low temperature of $10^{\circ} \mathrm{C}$, and lipid production and wastewater treatment efficiency achieved the desired results.

Comparison with traditional wastewater treatment processes In traditional wastewater treatment processes, the simultaneous removal of COD, nitrogen, and phosphorus was difficult to realize in a single stage of conventional wastewater treatment. In order to further remove nitrogen and phosphorus from the wastewater, the new process 
Table 3 Comparison of molasses wastewater treatment by different methods (Trophic mode of microalgae in table is heterotrophic cultivation)

\begin{tabular}{|c|c|c|c|}
\hline Methods & Temperature & Removal performance & References \\
\hline Microalgae and activated sludge & $25 \pm 1{ }^{\circ} \mathrm{C}$ & COD $\sim 78 \%$, TN $\sim 35 \%$ & [45] \\
\hline Ozonation and activated sludge & $25^{\circ} \mathrm{C}$ & COD 66.5\% & {$[50]$} \\
\hline Microbial fuel cells (MFC) & Not given & COD $\sim 79.8 \%$ & [51] \\
\hline Single chamber MFC & Not given & COD 89-90\% & [52] \\
\hline AFBR and microalgae pond & $27-32^{\circ} \mathrm{C}$ & COD 98.2\%, TN 85.5\% & [53] \\
\hline ABR & Not given & COD 90\% & [54] \\
\hline $\mathrm{BioH}_{2}-\mathrm{BioCH}_{4}-\mathrm{MFC}$ integrated system & $35^{\circ} \mathrm{C}$ & COD $\sim 98 \%$ & {$[55]$} \\
\hline UASB & $35^{\circ} \mathrm{C}$ & COD $\sim 91.2 \%$ & [56] \\
\hline Microalgae alone & $10^{\circ} \mathrm{C}$ & COD 87.2\%, TN 90.5\%, TP 88.6\% & This study \\
\hline
\end{tabular}

such as anaerobic/anoxic/oxic (AAO) process had to be added in traditional activated sludge process [57]. However, the control of combined systems was usually complicated, and additional treatment units had to be added, which were mentioned above. In this study, better COD, $\mathrm{TN}$, and TP removal were achieved in a single microalgae unit, which had significant advantage over activated sludge process.

Sludge separation and disposal were also troublesome in traditional wastewater treatment. On one hand, the sludge had to be separated with water in activated sludge process, which was often time- and labor-consuming [58]. However, the microalgal cultures could be easily obtained by simple setting or centrifugation to recycling and reutilization because of interaction and self-aggregation of microalgal cells. On the other hand, the disposal of massive sludge formed in wastewater treatment process was complicated. In this process, large amount of greenhouse gases $\left(\mathrm{N}_{2} \mathrm{O}, \mathrm{CH}_{4}\right.$, and $\left.\mathrm{CO}_{2}\right)$ were also produced following the conversion of organic matters in wastewater [59]. However, wastewater treatment by microalgae could avoid the problems above, because no sludge took part in this treatment unit and the produced $\mathrm{CO}_{2}$ could be utilized by microalgal cells.

In a word, the simultaneous lipid production and nutrient removal from molasses wastewater at low temperature conditions was of great significance, providing a novel approach for wastewater treatment in winter or spring of some region or country, such as in the north region of China. In the future work, microalgal cultivation will be combined with the treatment of other wastewater at low temperature, to verify the feasibility of microalgae wastewater treatment system.

\section{Conclusions}

The growth and lipid accumulation of microalgae mutant Scenedesmus sp. Z-4 were inhibited at the low temperatures of 4,10 , and $15{ }^{\circ} \mathrm{C}$. Although the lower lipid productivity were obtained at $10{ }^{\circ} \mathrm{C}$, less energy input were needed with more net energy output, compared to the optimal temperature of $25{ }^{\circ} \mathrm{C}$. When molasses wastewater was used as the substrate, the COD, TN, and TP removal rate at the low temperature of $10{ }^{\circ} \mathrm{C}$ reached $87.2,90.5$, and $88.6 \%$, under optimal condition of COD of $8000 \mathrm{mg} \mathrm{L}^{-1}$, inoculation ratio of $15 \%$, and $\mathrm{C} / \mathrm{N}$ of 15 . These results showed that microalgae had a great potential for the simultaneous wastewater treatment and energy recovery in low temperature regions.

\section{Additional file}

Additional file 1: Figure S1. Time course profiles of biomass and lipid accumulation for strain Z-4 at $25^{\circ} \mathrm{C}$. Table $\mathbf{S 1}$. The main components (mass percentage) of waste molasses in this study. Table S2. A comparison of cell growth, lipid accumulation, compositions of fatty acids, cellular components and glucose consumption at different temperatures.

Abbreviations

COD: chemical oxygen demand; TN: total nitrogen; TP: total phosphorus; AS: activated sludge; HRT: hydraulic retention time; AFBR: anaerobic fixed bed reactor; ABR: anaerobic baffled reactor; AAO: anaerobic/anoxic/oxic; MFC: microbial fuel cells; UASB: upflow anaerobic sludge blanket.

Authors' contributions

CM designed the study, executed the experimental work and data interpretation, and drafted the manuscript. BL participated in experimental design and data interpretation, and revised the manuscript. DX commented on the manuscript and contributed to the design of the study. HW, XP, and JZ all helped the calculation of energy input and output in the process of biodiesel production. NR contributed to the design of the study and data interpretation, and reviewed the manuscript. All authors contributed intellectually via scientific discussions during the work. All authors read and approved the final manuscript.

Acknowledgements

Thanks to the National Natural Science Foundation of China (Nos. 51478139 and 51678186) and State Key Laboratory of Urban Water Resource and Environment (Harbin Institute of Technology) (No. 2017DX13).

Competing interests

The authors declare they have no competing interests. 


\section{Availability of supporting data}

The datasets used and/or analyzed during the current study are available from the corresponding author on reasonable request.

\section{Funding}

This study was supported by the National Natural Science Foundation of China (Nos. 51478139 and 51678186).

\section{Publisher's Note}

Springer Nature remains neutral with regard to jurisdictional claims in published maps and institutional affiliations.

Received: 6 February 2017 Accepted: 20 April 2017

Published online: 02 May 2017

\section{References}

1. Gao CF, Wang Y, Shen Y, Yan D, He X, Dai JB. Oil accumulation mechanisms of the oleaginous microalga Chlorella protothecoides revealed through its genome, transcriptomes, and proteomes. BMC Genom. 2014;15:1-14.

2. Halim R, Danquah MK, Webley PA. Extraction of oil from microalgae for biodiesel production: a review. Biotechnol Adv. 2012;30:709-32.

3. Brennan L, Owende P. Biofuels from microalgae-a review of technologies for production, processing, and extractions of biofuels and coproducts. Renew Sustain Energy Rev. 2010;14:557-77.

4. Miao X, Wu Q. Biodiesel production from heterotrophic microalgal oil. Bioresour Technol. 2006;97:841-6.

5. Scott SA, Davey MP, Dennis JS, Horst I, Howe CJ, Lea-Smith DJ. Biodiesel from algae: challenges and prospects. Curr Opin Biotech. 2010;21:277-86.

6. Le L, He H, Yang C, Shan W, Zeng G, Wu M. Nutrient removal and lipid production by Coelastrella sp. in anaerobically and aerobically treated swine wastewater. Bioresour Technol. 2016:216:135-41.

7. Hemalatha M, Mohan SV. Microalgae cultivation as tertiary unit operation for treatment of pharmaceutical wastewater associated with lipid production. Bioresour Technol. 2016;215:117-22.

8. Bashan LE, Bashan Y. Immobilized microalgae for removing pollutants: review of practical aspects. Bioresour Technol. 2010;101:1611-27.

9. Venkata MS, Rohit MV, Chiranjeevi P, Chandra R, Navaneeth B. Heterotrophic microalgae cultivation to synergize biodiesel production with waste remediation: progress and perspective. Bioresour Technol. 2015:184:169-78.

10. Bhatnagar A, Chinnasamy S, Singh M, Das KC. Renewable biomass production by mixotrophic algae in the presence of various carbon sources and wastewaters. Appl Energy. 2011;88:3425-31.

11. Devi MP, Venkata SG, Venkata MS. Heterotrophic cultivation of mixed microalgae for lipid accumulation and wastewater treatment during sequential growth and starvation phases: effect of nutrient supplementation. Renew Energ. 2012;43:276-83.

12. Cheng $S$, Xing D, Logan BE. Electricity generation of single-chamber microbial fuel cells at low temperatures. Biosens Bioelectron. 2011;26:1913-7.

13. Knoop S, Kunst S. Influence of temperature and sludge loading on activated sludge settling, especially on Microthrix parvicella. Water Sci Technol. 1998;37:27-35.

14. Rui SM, Bernard O, Gonçalves A, Bensalem S, Lopes F. Influence of temperature on Chlorella vulgaris, growth and mortality rates in a photobioreactor. Algal Res. 2016;18:352-9.

15. Sonmez C, Elcin E, Akin D, Oktem HA, Yucel M. Evaluation of novel thermo-resistant Micractinium and Scenedesmus sp. for efficient biomass and lipid production under different temperature and nutrient regimes. Bioresour Technol. 2016;211:422-8.

16. Pawar S. Effectiveness mapping of open raceway pond and tubular photobioreactors for sustainable production of microalgae biofuel. Renew Sustain Energy Rev. 2016;62:640-53.

17. Nwoba EG, Ayre JM, Moheimani NR, Ubi BE, Ogbonna JC. Growth comparison of microalgae in tubular photobioreactor and open pond for treating anaerobic digestion piggery effluent. Algal Res. 2016;17:268-76.
18. Åkerström AM, Mortensen LM, Bjørn R, Ragnar GH. Biomass production and removal of ammonium and phosphate by Chlorella sp. in sludge liquor at natural light and different levels of temperature control. Springerplus. 2016;5:1-13.

19. Ördög $V$, Stirk WA, Bálint $P$, Aremu AO, Okem A, Lovász C. Effect of temperature and nitrogen concentration on lipid productivity and fatty acid composition in three Chlorella strains. Algal Res. 2016;16:141-9.

20. Han F, Pei HY, Hu WR, Han L, Zhang S, Ma GX. Effect of high temperature stress on microalgae at the end of the logarithmic phase for the efficient production of lipid. Environ Technol. 2016;37(20):2649-57.

21. Ren HY, Liu BF, Kong FY, Zhao L, Ren NQ. Hydrogen and lipid production from starch wastewater by co-culture of anaerobic sludge and oleaginous microalgae with simultaneous cod, nitrogen and phosphorus removal. Water Res. 2015;85:404-12.

22. Satyawali Y, Balakrishnan M. Wastewater treatment in molasses-based alcohol distilleries for cod and color removal: a review. J Environ Manage. 2008;86:481-97.

23. Wilkie AC, Riedesel KJ, Owens JM. Stillage characterization and anaerobic treatment of ethanol stillage from conventional and cellulosic feedstocks. Biomass Bioenergy. 2000;19:63-102.

24. Zeng YF, Liu ZL, Qin ZZ. Decolorization of molasses fermentation wastewater by $\mathrm{SnO}$ (2)-catalyzed ozonation. J Hazard Mater. 2009;162:682-7.

25. Liu BF, Ma C, Xiao RN, Xing DF, Ren HY, Ren NQ. The screening of microalgae mutant strain Scenedesmus sp. Z-4 with rich lipid by ${ }^{60} \mathrm{Co}-\gamma$ ray mutation. Rsc Adv. 2015;5:52057-61.

26. Ren HY, Liu BF, Ma C, Zhao L, Ren NQ. A new lipid-rich Microalga scenedesmus sp. strain R-16 isolated using Nile red staining: effects of carbon and nitrogen sources and initial $\mathrm{pH}$ on the biomass and lipid production. Biotechnol Biofuels. 2013:6:143.

27. Abu-Ghosh S, Fixler D, Dubinsky Z, lluz D. Energy-input analysis of the life-cycle of microalgal cultivation systems and best scenario for oil-rich biomass production. Appl Energy. 2015;154:1082-8.

28. Benemann JR, Oswald WJ. Systems and economic analysis of microalgae ponds for conversion of $\mathrm{CO}_{2}$ to biomass. Nasa Sti/recon Technical Report N. 1994, 95.

29. Adesanya VO, Cadena E, Scott SA, Smith AG. Life cycle assessment on microalgal biodiesel production using a hybrid cultivation system. Bioresour Technol. 2014:163:343-55.

30. Wahlen BD, Morgan MR, Mccurdy AT, Willis RM, Morgan MD, Dye DJ. Biodiesel from microalgae, yeast, and bacteria: engine performance and exhaust emissions. Energy Fuel. 2012;27:220-8.

31. Sukačová K, Trtílek M, Rataj T. Phosphorus removal using a microalgal biofilm in a new biofilm photobioreactor for tertiary wastewater treatment. Water Res. 2015:71:55-63.

32. Yen HW, Chen PW, Chen LJ. The synergistic effects for the co-cultivation of oleaginous yeast-Rhodotorula glutinis, and microalgae-Scenedesmus obliquus, on the biomass and total lipids accumulation. Bioresour Technol. 2015;184:148-52.

33. Cheirsilp B. KitchaS, Torpee S. Co-culture of an oleaginous yeast Rhodotorula glutinis and a microalga Chlorella vulgaris for biomass and lipid production using pure and crude glycerol as a sole carbon source. Ann Microbiol. 2012;62:987-93.

34. Chi Z, Zheng Y, Jiang A, Chen S. Lipid production by culturing oleaginous yeast and algae with food waste and municipal wastewater in an integrated process. Appl Biochem Biotech. 2011;165:442-53.

35. Kitcha S, Cheirsilp B. Enhanced lipid production by co-cultivation and co-encapsulation of oleaginous yeast Trichosporonoides spathulata with microalgae in alginate gel beads. Appl Biochem Biotech. 2014;173:522-34

36. Dubois M, Gilles KA, Hamilton JK, Rebers PA, Smith F. Colorimetric method for determination of sugars and related substances. Anal Chem. 1955:28:350-6.

37. Liu Z, Gonzalez JS, Wang H, Gunasekaran S, Runge T. Dairy manure protein analysis using UV-vis based on the Bradford method. Anal Methods. 2015;7:2645-52.

38. Renaud SM, Thinh LV, Lambrinidis G, Parry DL. Effect of temperature on growth, chemical composition and fatty acid composition of tropical Australian microalgae grown in batch cultures. Aquaculture. 2002:211:195-214 
39. Thompson PA, Guo MX, Harrison PJ, Whyte JN. Effects of variation in temperature. II. On the fatty acid composition of eight species of marine phytoplankton. J Phycol. 1992;28:488-97.

40. Renaud SM, Zhou HC, Parry DL, Thinh LV, Woo KC. Effect of temperature on the growth, total lipid content and fatty acid composition of recently isolated tropical microalgae Isochrysis sp., Nitzschia closterium, Nitzschia paleacea and commercial species /sochrysis sp. (clone T.ISO). J Appl Phycol. 1995;7:595-602.

41. Reitan KI, Rainuzzo JR, Olsen Y. Effect of nutrient limitation on fatty acid and lipid content of marine microalgae. J Phycol. 2004;30:972-9.

42. Ball SG, Dirick L, Decq A, Martiat JC, Matagne R. Physiology of starch storage in the monocellular alga Chlamydomonas reinhardtii. Plant Sci. 1990;66:1-9.

43. Ho SH, Chen CY, Chang JS. Effect of light intensity and nitrogen starvation on $\mathrm{CO}_{2}$ fixation and lipid/carbohydrate production of an indigenous microalga Scenedesmus obliquus CNW-N. Bioresour Technol. 2012;113:244-52.

44. Travieso L, Benítez F, Sánchez E, Borja R, Martín A, Colmenarejo MF. Batch mixed culture of Chlorella Vulgaris, using settled and diluted piggery waste. Ecol Eng. 2006;28:158-65.

45. Gaurav K, Srivastava R, Sharma JG, Singh R, Singh V. Molasses-based growth and lipid production by Chlorella pyrenoidosa: a potential feedstock for biodiesel. Int J Green Energy. 2016;13:320-7.

46. Tsioptsias C, Lionta G, Deligiannis A, Samaras P. Enhancement of the performance of a combined microalgae-activated sludge system for the treatment of high strength molasses wastewater. J Environ Manag. 2016;183:126-32.

47. Zhang B, Chen S. Optimization of culture conditions for Chlorella sorokiniana using swine manure wastewater. J Renew Sustain Energy. 2015;7:19554

48. Arango L, Cuervo FM, González-Sánchez A, Buitrón G. Effect of microalgae inoculation on the start-up of microalgae-bacteria systems treating municipal, piggery and digestate wastewater. Water Sci Technol. 2016;73:687-96

49. Singhasuwan S, Choorit W, Sirisansaneeyakul S, Kokkaew N, Chisti Y. Carbon-to-nitrogen ratio affects the biomass composition and the fatty acid profile of heterotrophically grown Chlorella sp. TISTR 8990 for biodiesel production. J Biotechnol. 2015;216:169-77.
50. Tsioptsias C, Banti DC, Samaras P. Experimental study of degradation of molasses wastewater by biological treatment combined with ozonation. J Chem Technol Biot. 2016;91:857-64

51. Kubota K, Watanabe T, Yamaguchi T, Syutsubo K. Characterization of wastewater treatment by two microbial fuel cells in continuous flow operation. Environ Technol. 2016;37:114-20.

52. Lee YY, Kim TG, Cho KS. Characterization of the COD removal, electricity generation, and bacterial communities in microbial fuel cells treating molasses wastewater. J Environ Sci Health A Toxic Hazardous Subs Environ Eng. 2016;51:1131-8.

53. Travieso L, Benítez F, Sánchez E, Borja R, León M, Raposo F. Assessment of a microalgae pond for post-treatment of the effluent from an anaerobic fixed bed reactor treating distillery wastewater. Environ Technol. 2008;29:985-92.

54. Zhu Y, An D, Hou L, Liu M, Yu S. Treatment of decentralized molasses wastewater using anaerobic baffled reactor. Desalin Water Treat. 2016;57:1-6.

55. Yun J, Lee YY, Choi HJ, Cho KS. Process contribution evaluation for cod removal and energy production from molasses wastewater in a $\mathrm{BiOH}_{2}-$ $\mathrm{BioCH}_{4}-$ MFC integrated system. Bioproc Biosys Eng. 2017:40:55-62.

56. Yun J, Lee SD, Cho KS. Biomethane production and microbial community response according to influent concentration of molasses wastewater in a UASB reactor. Appl Microbiol Biotechnol. 2017;100:4675-83.

57. Zhou Z, Shen X, Jiang LM, Wu Z, Wang Z, Ren W. Modeling of multimode anaerobic/anoxic/aerobic wastewater treatment process at low temperature for process optimization. Chem Eng J. 2015;281:644-50.

58. Qian LL, Wang SZ, Xu DH, Guo Y, Tang XY, Wang LS. Treatment of municipal sewage sludge in supercritical water: a review. Water Res. 2016:89:118-31.

59. Mikosz J. Analysis of greenhouse gas emissions and the energy balance in a model municipal wastewater treatment plant. Desalin Water Treat. 2016;57:1-9.

\section{Submit your next manuscript to BioMed Central and we will help you at every step:}

- We accept pre-submission inquiries

- Our selector tool helps you to find the most relevant journal

- We provide round the clock customer support

- Convenient online submission

- Thorough peer review

- Inclusion in PubMed and all major indexing services

- Maximum visibility for your research

Submit your manuscript at www.biomedcentral.com/submit
O Biomed Central 